\title{
Is Cognition an Attribute of the Self or It Rather Belongs to the Body? Some Dialectical Considerations on Udbhațabhatța's Position against Nyāya and Vaiśeșika
}

\author{
Krishna Del Toso \\ University of Trieste, Trieste, Italy. \\ Email: krishna.deltoso@gmail.com \\ Received October 14 ${ }^{\text {th }}, 2011$; revised November 15 $5^{\text {th }}, 2011$; accepted November $20^{\text {th }}, 2011$.
}

\begin{abstract}
In this article an attempt is made to detect what could have been the dialectical reasons that impelled the Cārvāka thinker Udbhațabhatța to revise and reformulate the classical materialistic concept of cognition. If indeed according to ancient Cārvākas cognition is an attribute entirely dependent on the physical body, for Udbhațabhatta cognition is an independent principle that, of course, needs the presence of a human body to manifest itself and for this very reason it is said to be a peculiarity of the body. Therefore, Udbhatabhatta seems to describe the cognizing faculty according to a double ontology: it is both a principle and a characteristic, both independent and dependent. Two philosophical contexts_-Vaiśeșika and Nyāya schools — are here taken into account as possible anti-Cārvāka fault-finding points of view that spured Udbhațabhața to reconsider the Cārvāka perspective. Although we do not have so much textual material on this particular aspect of the ancient and medieval philosophical debate in India, it nonetheless can be supposed that Udbhațabhatta's reformulation of the concept of cognition was a tentative response to the Vaiśeșika idea that cognition is not an attribute of the body, rather of the mind (which is here supposed to be eternal), and to the Naiyāyika perspective according to which cognition would be an attribute of an everlasting self. In the case of the Nyayya school, fortunately we have at our disposal the criticism put forward by Vātsyāyana against the materialistic conception of cognition during this time. By examining some Vātsyāyana's objections, it will emerge that Udbhațabhațta's idea of cognition really seems to have the aspect of a consistent answer to them, from a renewed materialistic point of view.
\end{abstract}

Keywords: Cognition, Cārvāka Materialism, Udbhațabhațța, Vaiśeșika, Nyāya, Vātsyāyana

\section{Introduction}

This paper is to be considered as a philosophic exercise based on what can be called a case study because here I will take into consideration a particular aspect of the discussion concerning the nature of cognition (caitanya, buddhi, jñanna etc.) ${ }^{1}$ according to three different philosophical perspectives, which are on the one hand, the "reformed" Cārvāka materialism of Udbhațabhatța (or Bhattodbhața, $8^{\text {th }}-9^{\text {th }}$ century CE?) and, on the other hand, both the classical Vaiśeșika and Vātsyāyana's Naiyāyika points of view. It is a philosophic exercise because, in spite of the paucity of the sources available at present on Udbhatabhatta's thought, an attempt is here proposed to make two different philosophical contexts - Cārvāka and Nyāya-Vaiśeși$\mathrm{ka}$ - interact critically on the same subject, namely, the idea of cognition. Furthermore, I will try to give some indication on the possible reasons for Udbhațabhațta's reformulation of the classical Cārvāka concept of cognition, on the basis of Vaiśeșika and Nyāya material.

\section{Classical Cārvāka View on Cognition}

Even if only very few fragments of the Cārvākas' aphorisms have reached us, from the extant excerpts fortunately we can infer the general position on cognition upheld by the adherents

\footnotetext{
${ }^{1}$ As a preliminary note it has to be underlined that with "cognition" I mean here both knowledge (cognition of objects) and self-awareness (cognition of oneself or of one's self). This is because it seems to me that within the Cārvāka philosophy caitanya sometimes can stand for "knowledge" (buddhi, jūāna), whereas some other times for "consciousness" (caitanya tout court).
}

to this school. The materialistic perspective on cognition peculiar to the classical Cārvāka system is, hence, summarized by the following aphorisms: ${ }^{2}$

01. prthivyāpastejovāyur iti tattvāni

"Earth, water, heat and air are the principles".

02. tatsamudāye śarīrendriyavișayasamjñāh

"What is called "body", "sense organs", "object" [takes place] in the combination of those [principles]".

03. tebhyaś caitanyam

"Out of those [there is] cognition".

04. kinvādibhyo madaśaktivat

"Like the inhebriating power [that takes place] out of ferments and so on".

05. caitanyaviśiștah kāyah puruṣah

"The man is [nothing but] a body characterized by cognition".

06. śarìre bhāvāt |

"Because of the existence/appearance [of cognition only] when there is a body".

From these aphorisms we deduce that, according to the Cārvākas, the material elements are only four, and that these elements constitute not only the physical body (śarîra, kāya) and the external objects (visaya), but also cognition (caitanya), which appears in the body as, for instance, the alcoholic power in a hotchpotch of juices, ferments, sugar, etc. Consequently, the

\footnotetext{
${ }^{2}$ For the full list (with all the references) and translation of the extant Sanskrit fragments of the Cārvākas see Bhattacharya (2009: pp. 78-92), from which I quote with little adaptation. All the passages from Sanskrit texts referred to in this paper have been, when necessary, adapted to the quotation style used here, without of course changing the structure and meaning.
} 
human being is here reduced to a very particular mixture of physical elements, characterized by the presence of a cognizing faculty, which is likewise physical. Anantavirya $\left(10^{\text {th }}-11^{\text {th }}\right.$ centuries CE), in his Siddhiviniścayatīkā (Explanation of The ascertainment of logical demonstrations), informs us that one of the adherents to the classical Cārvāka philosophy, viz. Purandara, theorized that the arising of cognition from a mass of elements is possible only when those very elements assume a certain and well-determined shape. In all the other cases, cognition would not appear: ${ }^{3}$

07. mūrtasya prthivyādicatuștayasya jñānam anena pauram matam darśitam |

"[There is appearance of] cognition of the four [elements such as] earth etc., [only when they are] settled into a fixed shape. By means of this, the opinion of Paura[ndara] is explained".

Unfortunately, the exiguity of Purandara's and other classical Cārvākas' fragments at our disposal does not allow us to know in detail which was his conception of cognition. In any case, on the basis of our aphorism 05 . we can suppose also that the fixed shape (mürta), needed for the appearance of cognition, to which Purandara alludes to, were the human figure.

However, even if we agree to consider cognition as somehow dependent on the material elements (aphorism 03.) only when they assume the form of a human body (quotation 07.), we still have to solve the problem of defining which kind of relation exists between the body and cognition itself. Indeed, the passage 07. shows us a Purandara's reasoning on the cognizing faculty that, although it is evidently based on the abovementioned aphorism 05., unfortunately does not provide in itself any further explanation of that very aphorism. In other words, we still do not know whether cognition is a product of the material body, or if it is rather some material thing, which is added to the body. Indeed, this one is the crucial philosophical problem related to the cognizing faculty. More precisely, the question is whether the relation between body and cognition is similar to the one between cause and effect, or to the one between substance and its attribute(s).

This should have been a fundamental matter of discussion also within the Cārvāka cyrcles, as it emerges from for instance the different interpretations assigned by Cārvākas to some of the abovementioned aphorisms. In particular, it is worth noting here that aphorism 03 . accounts for at least two readings on the basis of both grammatical and semantic considerations. Grammatical considerations, because the term tebhyah can be intended either as a dative ("to them") or as an ablative case ("from them"). Semantic considerations, because the absence of a verb specifying the nature of the relation between the terms involved in the sentence is undoubtedly problematic. These ambiguities led at a certain point to two parallel commentarial positions on that aphorism, as Kamalaśila ( $8^{\text {th }}$ century CE) clearly points out in his Tattvasamgrahapañjikā (Running commentary on The collection of philosophical principles) $:^{4}$

08. tatra kecid vrttikārā vyācakșate utpadyate tebhyaś caitanyam | anye abhivyajyata ity āhuh | atah pakșadvayam āha jayate vyajyate' tha cet $i$

"There, some commentators explain that "consiousness originates from those [principles]"; others say "[cognition] is manifested". Therefore, they set forth a double position:

\footnotetext{
${ }^{3}$ Quoted from Bhattacharya (2009: p. 83).

${ }^{4}$ Tattvasamgrahapañjikā ad Tattvasamgraha (The collection of Philosophical Principle) verses 1857-1858 (Śāstrīi, 1968: p. 633).
}

"[cognition] is born" and "[cognition] is manifested".

Hence, according to the first interpretation, cognition originnates (utpadyate), or comes into being (jayate), from the mixture of material elements. The verbs utpadyate and jayate convey the idea of a somehow productive relation between two factors, one of which plays the role of cause and the other the role of effect. In this case, the link between cognition and body could be philosophically interpreted according to at least two perspectives. On one side, cognition could be considered as an attribute of the body, which is therefore its substance (this position is in accordance with our aphorism 05., where the human body is defined caitanyaviśișta, "characterized by cognition»). On the other side, cognition could be thought as the effect of the body, with the specification that the two must be necessarily involved in a particular kind of causal relation in which, when the cause ceases, the effect does not survive to it in any way (this is a possible reading of the abovementioned aphorism 06.). ${ }^{5}$

The second perspective referred to by Kamalasíla recalls the idea that the elements are not the cause stricto sensu, rather the occasion for the apparition of cognition (note the passive forms abhivyajyate, vyajyate, "is manifested"): in this case, cognition would somehow (but unfortunately our sources do not allow us to understand exactly how) differ from the four elements, although existing in dependence on them. If the first position (utpadyate, jayate) seems to represent the classical Cārvāka perspective, the second one (abhivyajyate, vyajyate) depicts or, better, anticipates the so-called "reformed" Cārvāka philosophy of Udbhațabhaț̣a. ${ }^{6}$

Cakradhara ( $11^{\text {th }}$ century CE), in his Granthibhainga (Breaking the knot), a commentary on Jayantabhatța's ( $9^{\text {th }}$ century CE) Nyāyamañjarī (The flower of Nyāya), appears to be more accurate in explaining which are the fundamental distinctions between the two perspectives. In doing that, he also informs us that the first position, besides other ancient Cārvāka thinkers, was upheld by Bhāvivikta: ${ }^{7}$

09. cirantanacārvākair hi bhāviviktaprabhrtibhih bhütebhyaś caitanyam iti sūtram bhütebhya iti pañcamyantapadayojanayā vyākhyātam bhūtebhya utpadyate caitanyam iti $\|$ udbhațena tu bhūtebhyah itipadam caturthyantatayā vyākhyātam bhūtebhyaś caitanyam bhūtārtham caitanyạ svatantram eva śarīrārambhakabhūtopakārakam ity arthah $\|$

(Indeed, by the ancient Cārvākas, beginning with Bhāvivikta, the aphorism "bhütebhyaś caitanyam" is explained with the use of the term bhütebhya in the fifth [ablative]

\footnotetext{
${ }^{5}$ Unfortunately, we do not have any witness of what Cārvākas thought about causal relations except for a fragment from Vādidevasūri's Syādvādaratnākara (The jewel mine of the doctrine of "may be"), where Udbhațabhaț̣a's conception of effect is referred to (Osval, 1988: p. 764): yatra tu bhattodbhațah prācīkațat | na hy atra kāranam eva kāryātmatām upaiti yata ekasyākāranātmana ekakāryarūpatopagame tadanyarūpābhāvāt tadanyakāryàtmanopagatir na syāt | kị tv apūrvam eva kasyacid bhāve prāgavidyamānam bhavat tat kāryam |. I propose the following translation: "Whereas Bhattodbhata demonstrated that in this case the cause itself does not obtain the nature of the effect since, when there is assimilation/acquisition of the essential form of a certain effect by something that is not a cause, then it [i.e., that non-cause] could not get the nature of the effect [which is] other than that [cause], because it has not the essential form of the other [i.e., of the cause]. Nonetheless, that which is completely new, [and although having being] formerly absent, [becomes] existent when something [else] is present, that is the effect». Quoted-but not translated-also in Bhattacharya (2009: p. 82).

${ }^{6}$ For a discussion on these two positions see Bhattacharya (2010b: pp. $537-$ 539).

${ }^{7}$ Quoted from Bhattacharya (2009: p. 81).
} 
case: "from the elements, cognition originates". But by Udbhata the word bhütebhya is explained with the fourth [dative] case: "to the elements, cognition [is added]"; indeed, cognition is [for Udbhațabhața] a material object, [which is] independent [but] auxiliary to the elements that constitute the body. This is the meaning).

\section{Udbhațabhaț̣a's New Approach}

The main point that distinguishes Udbhațabhatța's from Bhāvivikta's perspective, as can be inferred from our quotation 09 ., is the idea that cognition would be a material (bhütārtha), selfdependent (svatantra) element, which nonetheless needs the presence of a likewise material body for manifesting itself (see the abovementioned aphorism 06.). Hence, Udbhațabhatța see$\mathrm{ms}$ to describe a cognition that is actually a principle (because of its being svatantra, "self-dependent"), but a non-primary principle (because it is bhītopakāraka, "subsidiary to the elements"). In this very consideration lies the fundamental differrence between cognition, on the one hand, and earth, water, heat and air (that could be consequently considered as primary principles), on the other hand. Once again, it is Cakradhara who helps us to better understand Udbhațabhatta's thought: ${ }^{8}$

10. tatra hi prthivyāpastejovāyur iti ya itiśabdah sa evam prāyaprameyāntaropalakșanatvena tasyābhimatah |

"There, indeed, [in the sütra] "prthivyāpastejovāyur iti" the word iti is thus supposed by him [scil. Udbhatabhatța] to imply similar objects of knowledge, [but] different [from earth, water, heat and air]".

Besides the four material elements - we infer from this passage-Udbhatabhatta supposes the existence of other elements that remain unmentioned in the aphorism, but implicitly forshadowed by the particle iti ("thus"). Vādidevasūri $\left(12^{\text {th }}\right.$ century $\mathrm{CE}$ ), in his Syādvādaratnākara (The jewel mine of the doctrine of "may be"), confirms to us that this was the original perspective of Udbhațabhatța: ${ }^{9}$

11. yadā cașta bhațtodbhațh itiśabdah pradarśanaparo na punah samāptivacanaś caitanyaśabdasukhaduhkhecchādveșaprayatnasamskāāānām tattvāntaratvāt |

"Whereas, Bhattodbhața said [that] the word iti is nothing but illustrative and is not [at all] an indication of conclusion, because of the [existence of the] other principles of cognition, sound, pleasure, pain, desire, aversion, effort and subliminal impressions".

Moreover, Cakradhara elucidates as follows Udbhațabhațta's position on the relation existing between cognition and the physical body: ${ }^{10}$

12. yathā udbhatenoktam śarīrārambhakakārañānām eva bhūtānām sa kaścit tādrśso vicitrasukhaduhkhopabhogado dharmah svabhāvaviśeșa ity arthah |

"As said by Udbhața, this [cognition] is such a certain property, [which is capable of] enjoying the various pleasures and pains, a particular intrinsic nature of just the elements that are the causes that constitute the body. Thus is the meaning".

This excerpt reminds us of the abovementioned aphorism 05 ., where cognition is described as a characteristic of the body. Also in the present case, indeed, cogniton is defined by Udbhațabhatta as a property (dharma) or an intrisic attribute (svabhāvaviśeșa) of the four elements, but only (eva) when they are

\footnotetext{
${ }^{8}$ Quoted from Bhattacharya (2009: p. 81).

${ }^{9}$ Quoted from Bhattacharya (2009: p. 82).

${ }^{10}$ Quoted from Bhattacharya (2009: p. 81).
}

mixed up in the shape of a human body (śarira; see the passage 07., quoted above). This very property is what experiences the different feelings to which the body is subjected. Furthermore, the parallel reading of the passages 11 . and 12. suggests to us that also those feelings like pleasure, pain, desire etc., should be considered as peculiar properties of the physical body, because they share a similar nature with cognition. All this helps us to understand the nature of the auxiliary principles: they are principles because they are svatantra ("self-dependent"), but they are in a certain way properties because they are bhütopakāraka ("auxiliary to the elements"). Put it in another-somehow contradictory - way, they are self-based properties.

However, why did Udbhațabhatta deviate from the classical Cārvāka perspective on cognition? Why did he feel the need for developing a definition of cognition, which is more sophisticated than the one accepted by the ancient Cārvākas? Is this due to the fact that, like apparently other Cārvākas, Udbhațabhaț̣a accepted within his philosophical horizon some tenets belonging to other traditions of thought such as the Nyāya and/or the Vaiśeșika (as scholars generally believe) ${ }^{11}$ Well, I think that, even if it could be, in this case it is not unlikely to suppose that Udbhatabhatta reconsidered the materialistic concept of cognition because at a certain point Cārvākas had to face up to many opponents who articulated more and more their rebuttals against the idea that cognition could be a simple effect or attribute of the material elements. ${ }^{12}$ Therefore, in order to give more internal consistence to his theories in the light of the criticism put forward by the non-materialists, as was the case of the objections discussed below and raised against Cārvāka philosophy by Vātsyāyana $\left(5^{\text {th }}\right.$ century CE) in his Nyāyasūtrabhāṣya (Commentary on The Nyaya aphorisms), it is not impossible that Udbhațabhatța tried to find new interpretations of some problematic Cārvāka aphorism.

First of all, with the aim of giving more substance to this perspective, let us take into consideration the Vaiśeșika notion of cognition. If Udbhațabhatța was really influenced by this philosophical school, the outline of his possible dialectical interactions with Vaiśeșikas will help us to understand in what the two ideas of cognition differ.

\section{Udbhațabhaț̣a and the Vaiśeșikasūtras on Cognition}

The abovementioned Udbhațabhatta's passages give the impression that, in developing his point of view on cognition, he took care in distinguishing his own understanding of the nature of the cognizing faculty from the Vaiśeșika understanding of the same concept. Indeed, if we look at the Vaisessikasütras (The Vaiśssika aphorisms, compiled around the turn of the common era and traditionally attributed to the sage Kanāa),${ }^{13}$ we remark that the substances and the qualities admitted here are (Vaiśeșikasūtra 1.1.4-5):

\footnotetext{
${ }^{11}$ Consider for instance Bhattacharya (2010a: p. 423): "Aviddhakarna and Udbhața were basically Naiyāyikas. Even if they were converted to the Cārvāka/Lokāyata, they brought the whole baggage of Nyāya-Vaiśeșika terminology when they composed their commentaries on the Cārvākasütra". A similar opinion on Aviddhakarna has been upheld by Solomon (1972); see also Solomon (1977-1978).

${ }^{12}$ Consider the following opinion of Halbfass (1991: p. 293): "the old [Cārvāka] ideas attributed to Bṛhaspati and Purandara were adjusted, modified, and refined in response to the arguments presented by the Hindu and Buddhist opponents".

${ }^{13}$ For an outlook on the Vaiśeșikasūtras see, among others, Matilal (1977: pp 53-59). All the quotations from the Vaisessikasuttras, and the relative numbers of the aphorisms, when not specified otherwise, are here referred to from Jambuvijayaji (1961).
} 
13. prthivyāpastejovāyurākāśamkālodigātmāmaneti dravyānii

"The substances are earth, water, heat, air, ether, time, space, self and mind".

14. rūparasagandhasparśạḥ saṃkyāḥ parimānāni prthaktvam samyogavibhāgau paratvāparatve buddhayah sukhaduhkhe icchādveșau prayatnaś ca guñāh |

"The qualities are form/colour, taste, odour, touch, number, weight, distinctiveness, conjunction, separation, otherness, non-otherness, cognition, pleasure, pain, desire, aversion and effort".

Besides the elements barely material, according to Vaiśeșikas there are other non strictly material principles, such as time or space. But what is worth noting here is that some among the qualities listed in aphorism 14.- - cognition, pleasure, pain, desire, aversion and effort - are the same that Udbhațabhatța considered to be principles (see quotation 11.), which have the nature of properties (see quotation 12.) of material bodies. Because of the almost identical order according to which these qualities are listed in both cases, it can be argued that Udbhatabhațta could have been actually influenced by the Vaiśeșikas. For instance, he could have derived from the Vaiśeșikas the very idea that cognition, pleasure etc.-because they need a substratum for actually taking place-should necessarily have the nature of quality or property. What makes the fundamental difference between Vaiśeșika philosophy and Udbhațabhața is the following point: for Udbhațabhațta, cognition, pleasure etc. are all independent attributes of the physical body, whereas for Vaiśeșikas, on the one hand, cognition is thought as a sign of the mind (manas) and, on the other hand, pleasure, pain, desire, aversion and effort are thought as signs of the self (ātman), the body being here confined to a secondary level or role. Indeed, as concerning the mind, we read (Vaiśeșikasūtra 3.2.1):

15. ātmendriyārthasannikarșe jūānasyābhāvo bhāvaś ca manaso lingam

"When there is contact between self, senses and object, the presence or absence of cognition is the mark of the mind".

Moreover, concerning the self we have the following aphorism (Vaiśeșikasūtra 3.2.1):

16. prānāpānanimeșonmeșajīvanamanogatīndriyāntaravikārāḥ sukhaduḥkhe icchādveșau prayatnaś cety ātmalingā$n i$

"The marks of the self are prāna and apāna [breaths], closing and opening of the eyes, vital and mental motions, alteration of [some sense with] another sense, pleasure, pain, desire, aversion and effort".

To that, it must be added that both mind and self are by the Vaiśeșikas believed to be everlasting substances. The following aphorism, repeated twice (once referring to the mind and once to the self) clarifies exactly this point (Vaiśeșikasūtra 3.2.2, 5):

17. dravyatvanityatve vāyunā vyākhyāte |

"[Its] substance-hood and permanence are explained by [the reference to] the air [which is unseen but existent]". 14

\footnotetext{
${ }^{14}$ The term vāyunā, "by the air" here refers to the arguments in favour of the permanence of the air contained in Vaiśeșikasūtra 2.1.11 (adravyavattvād dravyam; "[The air] is a substance because of [its] non inherence to [other] substances") and 2.1 .13 (adravyavattvena nityatvam uktam; "The permanence [of the air] is affirmed by means of [its] non inherence to [other] substances"). The same reasoning, according to our aphorism 17., should be applied to the self and the mind.
}

It is because the mind and the self are conceived as eternal, not strictly material elements, that they are denied by the materialist Cārvākas, who cannot admit that something does actually survive to the death of the body. ${ }^{15}$ Even if we do not have any specific fragment bearing witness on Udbhațabhatta's position on this particular issue, it is not difficult to imagine that also him, like all the other Cārvākas, accepted this perspective. Consequently, in theorizing the attributive nature of cognition, pleasure, pain etc., Udbhațabhața assigned to the body the status of their substratum. In doing so, he implicitly refuses the Vaiśeșika opinion that, on the one side, the mind is the actual substratum of $\operatorname{cognition}^{16}$ and, on the other side, the self is the actual substratum of pleasure, pain etc. To say the truth, Udbhatabhața probably had to face himself with a later Vaiśeșika theory, according to which cognition was listed among the attributes of the self, rather than among those of the mind. This suspect acquires more substantiality when we compare the list of the "other principles" in passage 11., quoted above, with the following excerpt from Candrānanda's (around $8^{\text {th }}-9^{\text {th }}$ century CE) Vaiśeșikasütravrtti (Glosses on The Vaiśeșika aphorisms)

\footnotetext{
${ }^{15}$ As fas as the theory of the existence of a former life is concerned, the Cārvāka perspective is summarized for instance in the extant Tibetan translation of Bhāviveka's ( $6^{\text {th }}$ century CE) Prajñāpradīpavrtti (Glosses called The lamp of wisdom) on Nāgārjuna's ( $2^{\text {nd }}$ century CE) Mūlamadhyamakakārikā (Root stanzas on the middle) stanza 16.1 (foll. 164a7b1): 'di ltar ma śi ba'i bar du gnas pa rnams la blo gcig kho nar zad pa' $i$ phyir te | de ltar re źig 'jig rten snia ma med do || ("Thus, because, until the[ir] death, there is nothing but one [faculty of] cognition for [each of] those who remain [in this world], hence, then, [it is to be concluded that] a former world does not exist"). Other Cārvāka arguments against the idea of a stream of consciousness underlying several existences is met with in the following excerpts. Tattvasamgrahapañjikā ad Tattvasamgraha verses 1871-1876 (Śāstrī, 1968: p. 637): punarukta deśāntarạ̣ kalāntaram avasthāntaram vā paralokah ("It is repeted [by the Cārvākas] that the world beyond [the present one] is another place, another time or another condition"). Tattvasaṃrahapañjikā ad Tattvasaṃraha verse 1938 (Śāstrī, 1968: p. 663): ihalokaparalokaśarīrayor bhinnatvāt tadgatayor api cittayor naikah santānah ("Because of the difference between the body in this world and [the body] in the world beyond, also the stream of the two cognitions that adheres [respectively] to those [two bodies] is not the same"). All these passages are referred to also in Bhattacharya (2009: p. 83), with the exception of the excerpt from Bhāviveka's Prajñāpradīpavrtti that is quoted there from a Sanskrit restoration provided by Sanjitkumar Sadhukhan (see Bhattacharya, 2009: p. 91). A text entirely devoted to the Buddhist rebuttal of the Cārvāka idea of the inexistence of a world beyond the present one is Dharmottara's ( $8^{\text {th }}$ century CE) Paralokasiddhi (The proof of rebirth), on account of which see Steinkellner (1986).

${ }^{16}$ See Candrānanda's Vaiśesikasütravrtti (Glosses on The Vaiśesika aphorisms) on Vaiśeșikasūtra 3.2.1 (Jambuvijayaji, 1961: p. 28): ātmendriyār- thānām sannikarșe yadabhāvāj jñānam na bhavati yadbhāve ca bhavati tad manah | evam jñānotpattyanutpattī manaso lingam | ("When there is contact of self, senses and objects, mind is that which, because of its absence, there is no cognition, while in its presence, there is [cognition]. Thus, the occurrence and non occurrence of cognition is the mark of the mind"). On the absence of cognition among the characteristics of the self in our aphorism 16. see Bronkhorst (1994: pp. 675-676). Within the philosophical Vaiśeșika horizon, cognition can be admitted as an attribute of the mind because the mind is considered to be a substance and not, as it happens in other systems of thought, an organ of sense (see below, note 23). In spite of its being a characteristic of the mind, cognition is in any case accepted among the proofs of the existence of the self, as Vaisesikasūtra 3.1 .2 is reputed to demonstrate: indriyārthaprasiddhir indriyärthebhyo'rthāntaratve hetuh ("The accomplishment of [the contact between] senses and objects [i.e., cognition,] is the proof of something different from senses and objects"). It is perhaps for this very reason that at a certain point in the development of Vaiśeșika philosophy, and notwithstanding the clear import of our aphorisms 15 . and 16. quoted above, cognition began to be considered a mark not of the mind, rather of the self, as we will see in a while.
} 
on Vaiśeșikasūtra 3.2.17: ${ }^{17}$

18. tasya guṇāh buddhisukhaduḥhecchādveșaprayatnādṛ̦țasamskārā vaiśeșikāh |

"Its [scil. the self's] peculiar qualities are cognition, pleasure, pain, desire, aversion, effort, the unseen [merit and demerit] and subliminal impressions".

The list is almost identical in both cases, except for a drssta ("the unseen", referring to karman, the moral law of cause and effect) in Candrānanda's passage, which is - so to speak-substituted by Udbhațabhațta with śabda ("sound"). In any case, the Vaiśeșika re-elaboration of the concept of "self", of which Udbhatabhatta was surely aware, does not invalidate in itself his dialectical position towards the classical Vaiśeșika dichotomy between the mind and the self. In sum, the point against which Udbhațabhaț̣a seems to hurl himself is the Vaiśeșika idea that cognition, pleasure etc., although they need a body for actually taking place, depend nonetheless primarily on the mind and the self (or on the self alone, according to Candrānanda): it is, indeed, the presence of the mind and the self that for Vaiśeșikas would allow the origination or the manifestation of cognition, pleasure etc. Therefore, a body devoid of a mind and a self could not-we infer from our aphorism 15.- - experience any cognition, pleasure and so on. On the contrary, according to Udbhațabhațta (and to Cārvākas in general), it is exactly because the occurrence of those events is observed to take place only when and where there is a body, that we should consider the body itself to be the actual basis for the intervention of cognition etc. (this is the primary meaning of our aphorism 06.). Consequently, the need for a mind and/or a self becomes completely unnecessary.

However, the materialistic reduction of psychological or psycho-physical events, such as cognition or pleasure, to the simple aggregation of four material elements, and the total denial of some non-physical substratum (mind, self or whatever), on which make those events depend, may have put Udbhatabhatța (and of course many other Cārvākas) in front of a serious problem. Indeed, in order to be consistent with the assumption that cognition, pleasure etc., are qualities or characteristics, the Vaiśeșikas admitted the mind and the self as their substantial substrata. Furthermore, the Vaiśeșika consideration that the mind and the self are substances quite different from the material elements that constitute the physical body represents a good position to explain why events like cognition or desire etc., notwithstanding their being qualities, do not manifest themselves in the same way in which other (physical) qualities, like form, taste etc., do. Indeed, being cognition, pleasure etc., psychological characteristics, the ancient Vaiśeșikas should have remarked that their intervention into or onto the substance (s) to which they adhere to, had to depend on precise and more articulated causes than the causes allowing the manifestation of a

\footnotetext{
${ }^{17}$ Jambhuvijayaji (1961: p. 31). Note the presence of "subliminal impressions" (samskāra) among the characteristics of the self. Another thinker, who flourished some century before Candrānanda, namely the Buddhist Bhāviveka, asserted a similar perspective in his Tarkajvālā. Bhāviveka, indeed, upheld that the Vaiśeșikas admitted the following qualities of the self (I quote from He, 2011: p. 25, note 8): blo dan | bde ba dain $\mid$ sdug bsinal ba

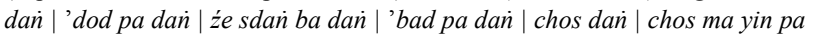
dan | śes pa dain |'dus byas ("Cognition, pleasure, pain, desire, aversion, effort, merit, demerit, knowledge and subliminal impressions"). He (2011: p 25) translates 'dus byas with "conditioned", thus interpreting this term as meaning samskrta. No doubt that here it is to be taken rather as the Tibetan translation of the Sanskrit samskāra. Bhāviveka belongs to the so called Vaiśeșika "dark period" (Matilal, 1977: pp. 59-62) and for this very reason his witness is particularly important for the reconstruction of the history of Vaiśeșika philosophy.
}

colour, of a form, and so on. To exemplify this point, we can say that a white stone of 21 pounds remains always a stone that is white and whose weight is 21 pounds: in this case the substance "stone" holds - so to speak - permanently the characteristics "white" and "21 pounds". Pleasure, on the contrary, rises in or on its very substance only on certain occasions, and when there is pleasure, generally there is not pain, which in its turn takes place on other occasions. To justify, on the one hand, the collection of all the cognitions, all the pleasures etc., experienced in one's life under a unifying principle that could guarantee the reference of all those psychological events to the one and the same person or body and, on the other hand, the fact that a body is not always affected by cognitions, pleasures etc., the Vaiśeșikas admitted the mind and the self as permanent substances - underlying bodies - of, respectively, cognition and pleasure, pain etc. Hence, for the ancient Vaiśeșikas the cognizing faculty can actually take place not merely when and where there is a body, but primarily where and when there is an active mind (which of course dwells in the body): in this way they explain why cognition does not always characterize the body. The same for the self with pleasure, pain etc.

The Cārvāka denial of any substance different from the body and able to support the cognizing faculty, the pleasures etc., could have represented a serious philosophical problem in the differentiation of bare characteristics (such as colour, form, and so on), which are observed to belong always to their characterized, from psychological events (such as cognition, desire etc.) that, albeit adhering to the same substratum, are nonetheless occasional. Hence, facing this consideration, the fundamental question could have been: how can we save the materialistic assumption of the inexistence of the self etc., and simultaneously justify the fact that, because cognition, pleasure etc., manifest themselves in one and the same body, but only on certain occasions, they - unlike the other characteristics - seem to have a sort of partial independence from their own substratum? Perhaps, it is because he was impelled exactly by problems of this kind that Udbhatabhatța theorized what could be called a new materialistic ontology of cognition, rethinking it in terms of svatantra (self-dependent). Of course, being both svatantra (self-dependent) and bhütärtha (material), cognition cannot obviously be a mere characteristic: indeed, characteristics are by definition paratantra, that is, "dependent on something other". 18 Therefore, if a certain thing is not a characteristic tout court, it must have also some aspect of the nature of the characterized, that is, of a principle, a tattva. However, cognition as a princeple is observed to take place only in the presence of a body (constituted in its turn by other principles). This means that, when a body is absent, also what depends on it does not occur: it is for this very reason-I suggest - that earth, water etc. are taken to be bhütas (elements) while cognition is defined by Udbhațabhaț̣a as bhütārtha (litt: "object/thing made by/based on elements"; see quotation 09. above). To put it in simple words, cognition in Udbhațabhațta's system of thought preserves its - so to speak - behaviour of property, without being exactly a property: it can be described as a secondary or auxiliary principle (that is, not a principle tout court). Transposed in more philosophical terms, we could say that Udbhațabhața's cognition seems to lie on a double ontology: it is a characteristic when compared with its substance (i.e., the body), but it is also

\footnotetext{
${ }^{18}$ In Vaiśeșikasütra 1.1.15, the author describes the nature of a quality (guna) as: dravyāśraȳ̄ agunavān ("Resting on a substance and not endowed with [other] qualities").
} 
an independent principle when compared with the other characteristics of its very substratum. ${ }^{19}$ A reasoning of such a kind could have been what led Udbhațabhatța to reformulate the Cārvāka idea of cognition.

Of course, all this would remain only a supposition, although likely, unless we find some further corroboration. I suggest here - also on the basis of the abovementioned familiarity of Udbhațabhatța with the Nyāya philosophy - that a possible argument in favour of this thesis could be (found) forshadowed in some passages of Vātsyāyana's $\left(4^{\text {th }}-5^{\text {th }}\right.$ century CE) Nyāyasūtrabhāṣya against materialism, with which Udbhațabhatța certainly had to face up to.

\section{Vātsyāyana on Cognition and His Criticism towards Materialism}

Before taking into account Vātsyāyana's reasoning, it will be helpful here to contextualize in brief the general, classical Nyāya perspective on cognition - as is drawn in the Nyayasütras (The Nyāya aphorisms) - and the subjects related to it. To begin with, we find that the principles admitted by the Naiyāyikas are five (Nyāyasūtra 1.1.13): ${ }^{20}$

\section{9. prthivyāpastejovāyurākāśam iti bhūtāni}

"Earth, water, heat, wind and ether are the elements".

Moreover, we are also reminded that several words are to be taken as synonyms referring to cognition (Nyāyasūtra 1.1.15):

20. buddhir upalabdhir jūānam ity anarthāntaram |

"Cognition, conception and knowledge have the same meaning".

On the basis of this specification we are allowed to consider all these three terms as indicating the same faculty. This is an important assumption for correctly interpreting the excerpts that follow. Taking these aphorisms as general premises, let us consider now the following one (Nyāyasūtra 1.1.10):

21. icchādveșaprayatnasukhaduḥkhajñānāni ātmano lingam iti

"Desire, aversion, effort, pleasure, pain and cognition are the mark of the self'.

What is worth noting here, is the fact that according to the Naiyāyikas, contrarily to what was asserted by the ancient Vaiśeșikas (see our aphorisms 15. and 16.), but in at least partial accordance with the abovementioned position of Candrānanda, also cognition is a characteristic of the self. However, like in the case of Vaiśeșikas, the Naiyāyikas accepted the existence of a self, ${ }^{21}$ which is conceived as an entity that, albeit its dwelling

\footnotetext{
${ }^{19}$ What has been called here "double ontology" - referring to a dialectical perspective - is to be considered as a quite different concept from Bhattacharya's (2010a: p. 424) "the dualist position adopted by Udbhața"-referring rather to a philosophical definition. See also Bhattacharya (2010a: pp. 423, 427-428). According to Bhattacharya (2010b: p. 538): "by saying that consciousness is independent of the four elements that constitute the human body Udbhața leaves the door open to a non-materialist position. The Cārvāka position was essentially monistic: no body, no consciousness". But, as we have seen, our quotation 12. prevents us to think that for Udbhatabhatta there could be actually any cognition without a body, a concept that seems to be somehow forshadowed also in quotation 09 ., where cognition is said to be bhütärtha, "an object/thing made by/based on the elements". Thus, the independence of cognition seems to be a concept that is dialectically (it is svatantra without exactly being svatantra), more than philosophically useful.

${ }^{20}$ All the quotations from the Nyāyasütras follow the edition Chandra, Sinha (1930).

${ }^{21}$ A discussion on the Naiyāyika proofs of the existence of the self is available, among others, in Chakravarti (1982).
}

within the body, survives to the physical or biological death (Nyāyasütra 1.1.9 mentions pretyabhāva, litt. "the state after death", as a peculiarity of the the self). Consequently, the body is described as nothing but the place or the means that allows the self's wordly experiences (Nyāyasūtra 1.1.11):

\section{2. ceștendriyārthāśrayah śarīram |}

"The body is the recipient of exertion, senses and [the feelings derived from] objects".

It is interesting, in this respect, to notice that Vātsyāyana, in his Nyāyasūtrabhāşya, clearly interprets the body as an instrument of the self. Introducing his discussion on the aphorism just quoted, he indeed writes: ${ }^{22}$

\section{3. tasya bhogādhișthānam |}

"[The body] is the basis of its [scil. self's] experiences".

The reason why the Naiyāyikas conceived the body as the seat of the sense organs can be, in my opinion, understood quite intuitively. Not so for exertion and objects, for which we need to have recourse to Vātsyāyana's interpretation: ${ }^{23}$

24. katham ceștāśrayaḥ | īpsitam jihāsitam vārtham adhikṛtyepsājihāsāprayuktasya tadupāyānușțhānalakșaṇā samīhā ceștā sā yatra vartate tac charīram | [...] katham arthāśrayah | yasmin āyatane indriyārthasannikarșād utpannayoh sukhaduhkhayoh pratisamvedanam pravartate sa eșām āśrayah tac charīram iti

"How [is the body] a recipient for exertion? Concerning a thing desired or avoided, exertion [consists in] the wishwhich aims at carring out the means for [obtaining or avoiding] that [thing] — of appropriate desire to obtain or desire to abandon; the place in which this [exertion] takes place is the body. [...] How [is the body] a recipient for objects? The enjoyment of pleasure and pain arisen because of the contact between senses and objects occurs where there is such a support [viz. the body, consequently] that which is the recipient of those [objects], is the body".

We conclude, hence, that the Naiyāyikas considered the self as the actual experiencer of cognition, desire, aversion, pleasure and pain, whereas the body would have a mere role of occasioning factor or, better said, of bare place for the occurrence of these very experiences. Furthermore, by not admitting - as, on the contrary, the ancient Vaiśeșikas did - the mind as substratum of cognition, ${ }^{24}$ the Naiyāyikas had to refer the articulation

\footnotetext{
${ }^{22}$ Sastri Tailanga (1984: p. 25).

${ }^{23}$ Sastri Tailanga (1984: pp. 25 - 26), with the following readings: tadup $\bar{a} y \bar{a}-$ nușthānalakșanam $\rightarrow$ tadupāyānușthānalakșan̄ā; varttate $\rightarrow$ vartate; yasminn $\rightarrow$ yasmin; utpannayoh sukhaduhkhayoh pravartate sa eșām āśrayah pratisamvedanam $\rightarrow$ utpannayoh sukhaduhkhayoh pratisamvedanam pravartate sa eșām āśrayah.

${ }^{24}$ The most important distinction between the ancient Vaiśeșika and the Naiyāyika psychologies lies in their different interpretation of the mind According to the Naiyāyikas, indeed, the mind is to be intended as having the nature of internal sense organ-even if it is not explicitly defined as such in the Nyāyasūtras. Vātsyāyana is quite clear on this point in his commentary on Nyāyasūtra 1.1.4 (Sastri Tailanga, 1984: p. 13): manasaś cendriyabhāvān na vācyam laksanāntaram iti| tantrāntarasamāeāāāc caitat pratyetavyam iti | paramatam apratișiddham anumatam iti hi tantrayuktih | ("And [mind] is not explicitly mentioned as another attribute [of perception, different from the five sense organs,] because of the nature of sense organ of the mind. This [notion] is to be admitted because of the customary [acceptance of it] in other systems [of thought]: it is indeed usage with [other] systems that an opinion different [from ours, when] not denied, is [implicitly] approved"). Whereas, the Vaiśeșikasūtras (Comba, 1987: p. 44): "never clearly state that the manas is an indriya, on the contrary they describe it as something very different from the sense organs: the manas is a substance (dravya), while the sense organs are made of substances but do not constitute separate substances; the manas is eternal, while the sense organs die with the body, because of their composite and elemental nature; the functions of the manas are totally different from the functions of sense organs [...]; every time that the sütras speak of the manas and of the sense organs, they are listed separately". For a clear survey on the philosophical import of Vaiśeșika into Vātsyāyana's thought see Thakur (2003: pp. 367-372).
} 
of all the psychological events to the self. ${ }^{25}$ This means that the self is not only what experiences the various feelings and desires, but it is also the actual knower of them. Hence, if the ancient Vaiśeșikas kept separated the feelings (referring to the self) from cognition (referring to the mind), the Naiyāyikas - as apparently some later Vaiśeșikas like Candrānanda-prefer to unify all these elements under one single factor, namely, the self. The self is thus capable of both knowing and feeling.

Now, it seems to me that Udbhațabhațta's idea of cognition conceptually followed more-so to speak - the "self" unifying principle of the Naiyāyikas, than the "self-mind" dichotomy proposed by the ancient Vaiśeșikas. Indeed, on the basis of the abovementioned passage 12., and considered the fact that Udbhațabhaț̣a, as specified above, could not admit the existence of a self without contravening the basic Cārvāka stance, we can easily understand why for him cognition must represent not only the knowing faculty (being it, by definition, the knowing faculty) of the body, but also what experiences pleasures, pains etc. In other words, Udbhațabhațta seems to confer to cognition the same role that in the Nyāya system is played by the self.

Now, keeping in mind all what precedes and considering it as a general premiss, let us turn our attention to a particular passage of Vātsyāyana's commentary on the Nyāyasūtras, from which we can take a sketch of the pre-Udbhațabhatța Cārvāka argumentation in favour of the physicity of cognition. According to Vātsyāyana's Nyāyasūtrabhāṣya ad Nyāyasūtra 3.2.3536 , the first of these two aphorisms would expound a theory, attributed to a general opponent, a partisan of materialism (called bhütacaitanika, a term referring to the upholder of the doctrine that cognition is from material elements, and recalling our aphorism 03.), according to whom activity (ärambha) and inactivity (nivrtti) - that in Nyāyasūtra 3.2.34 are said to be occasioned by desire and aversion (which are, in their turn, the marks/properties of the self, as our quotation 20 . clearily testifies) - would belong to the physical body. The second aphorism, on the contrary, represents the Naiyāyikas' answer: ${ }^{26}$

25. atra bhūtacaitanika āha | [Nyāyasūtra 3.2.35:] tallingatvād icchādveșayoh pārthivādyeșv apratiședhah || àrambhanivrttiling $\bar{a} v$ icchādveșāv iti yasyārambhanivrttī tasyecchādveșau tasya jūānam iti prāptam pārthivāpy ataijasavāyavīyānām śarīrānām ārambhanivrttidarśanād ic-

\footnotetext{
${ }^{25}$ To explain this point in brief, let us follow this reasoning. Nyāyasūtra 1.1.16: yugapaj jñ̄anannutpattih manaso lingam | ("The non-arising of simultaneous cognitions is the mark of the mind"). In this aphorism the function of the mind is limited to the simple sieving of the several cognitions coming from the senses and it does not, as in the abovementioned Vaiśeșikas' aphorims 15., constitute the primary element whose presence allows consequently the presence of cognition. The perspective put forward in Nyāyasuttra 1.1.16 represents the theoretical basis for Nyāyasūtra 3.2.19: yugapaj jñeyānupalabdheś ca na manasah | ("And [cognition does] not [belong] to the mind because of the non perception of simultaneous cognised objects"). Vātsyāyana comments on this last aphorism as follows (Sastri Tailanga, 1984: p. 168): yugapaj jñeyānupalabdhir antahkaranasya lingam tatra yugapaj jñeyānupalabdhyā yad anumīyate antahkaranam na tasya guno jñānam | kasya tarhi jñasya vaśitvāt | vaśi jñātā vaśyam karanam jñānagunatve ca karanabhāvanivrttih | ("The non perception of simultaneous cognised objects is the mark of the internal instrument [of cognition, scil. the mind]; therefore, by means of the non perception of simultaneous cognised objects, the internal instrument is inferred; [hence,] cognition is not a quality of that [internal instrument]. Of what then [is cognition a quality]? [It is the quality] of the cognizer [scil. the self], because of [its] being the controller. The controller is the knower and the controlled is the instrument, and if [the mind] had the quality of cognition, [there would be] cessation of [its] being an instrument"). Therefore, according to the Naiyāyikas, cognition cannot be the mark of the mind, rather it is the mark of the self. To the mind seems to belong the capacity of processing just one cognition at a time.

${ }^{26}$ Sastri Tailanga (1984: p. 174). The enumeration of the aphorisms in Sastri Tailanga's edition differs from ours as follows: Nyāyasūtra 3.2.35 is Sastri Tailanga's Nyāyasūtra 3.2.36, and Nyāyasūtra 3.2.36 is Sastri Tailanga's Nyāyasūtra 3.2.37.
}

chādveșajñānair yoga iti caitanyam |

[Nyāyasūtra 3.2.36:] paraśvādiṣv ārambhanivrttidarśanāt || śarīre caitanyanivrttih | ārambhanivrttidarśanād icchādveșajñānair yoga iti prāptam paraśvādeh karaṇasyārambhanivrttidarśanāc caitanyam iti | atha śarīrasyecchādibhir yogah paraśvādes tu karanasyārambhanivịttī vyabhicaratah na tarhy ayam hetuh pārthivāpy ataijasavāyavīyānām śarīrāṇām ārambhanivrttidarśanād icchādveșajñānair yoga iti

ayam tarhy anyo'rthah tallingatvād icchādveșayoh pārthivādyeșv apratiședhah | prthivyādīnām bhūtānām ārambhas tāvat trasasthāvaraśarīeșu tadavayavavyūhalingah pravrttiviśeșah loṣtādișu ca lingābhāvāt pravrttiviśeșābhāvo nivrttih | ārambhanivrttilingāv icchādveșāv iti pārthivādyeșv anuṣu taddarśanād icchādveșayogas tadyogāj jūānayoga iti siddham bhütacaitanyam iti kumbhādișv anupalabdher ahetuh | kumbhādimrdavayavānām vyūhalingah pravrttiviśeșa ārambhah sikatādiṣu pravrttiviśeșābhāvo nivrttih | na ca mrtsikatānām ārambhanivrttidarśanād icchādveșaprayatnajñānair yogaḥ | tasmāt tallingatvād icchādveșayor ity ahetur iti $\|$

"There, the adherent to the doctrine that cognition is from material elements says: [Nyāyasütra 3.2.35] "Because they are marks of those [activity and inactivity, which takes place only in presence of a body], there [can] not [be] negation of desire and aversion in these [bodies] made by earth etc." Desire and aversion are the marks of activity and inactivity; [therefore,] activity and inactivity [are characteristics] of some thing, of which [also] desire and aversion [are characteristics, and] it is proper [to think] that [also] knowledge [must be a characteristic] of that [very thing]; moreover, the [body] made by earthbecause activity and inactivity are observed [to be the marks] of bodies not [composed by] igneous and aereal [elements] — does possess desire, aversion and knowledge, and hence cognition.

[Nyāyasūtra 3.2.36] "[We Naiyāyikas reject all this,] because activity and absence of activity are observed in [inanimated things like] axes etc." [This functions as a] rebuttal of [the idea that] cognition is in the body. [If] it were proper [to admit] that the combination of desire, aversion and knowledge [belongs to the body] because activity and inactividy are observed [in it, then] cognition [should be a property also] of instruments like an axe etc., because activity and inactivity are observed [also there]. But, [if only] the body possesses desire etc., then activity and inactivity of instruments such as an axe etc. deviate from [your argument], and in that case this [of yours] is not a [valid] reason [for upholding that]: moreover, the [body] made by earth-because activity and inactivity are observed [to be the marks] of bodies not [composed by] igneous and aereal [elements] - does possess desire, aversion and knowledge.

[Objection by the materialist:] in that case, this [sūtra], "Because they are marks of those [activity and inactivity], there [can] not [be] negation of desire and aversion in these [bodies] made by earth etc." has [to be interpreted according to] another meaning. Activity is [a property] of elements like earth etc., insofar as there is a particular spontaneous attitude in moving or immovable [living] bodies, which is a mark of the component limbs of those [very bodies], and inactivity is the absence of that particular spontaneous attitude in [for instance] a lump of clay etc., because of the absence of that mark. Desire and 
aversion are the marks of activity and inactivity; as those [activity and inactivity] are observed in the atoms ${ }^{27}$ of those [elements like] the earthy one etc., there is conjunction with desire and aversion. Because there is conjunction with those [two], there is [also] conjunction with knowledge. Thus it is established that cognition [belongs] to elements.

[Answer: your argument] is not a [valid] reason because of the non perception [of activity and inactivity] in [objects like] a jar etc. [Indeed, if we follow your reasoning,] activity [should be also] a particular spontaneous attitude that is the mark of the [whole] structure of the portions of clay of a jar etc., and inactivity [should be] the absence of that particular spontaneous attitude in [things such as] gravel etc. [where there is no structure of parts]; but [in these inanimate things] there is not conjunction with desire, aversion, effort and knowledge [simply] because activity and inactivity of jars and gravel are observed. Therefore, "of desire and aversion, because they are marks of those" is not a [valid] reason».

The objection raised here by the hypothetical materialist can be summarized in the following terms: $(a)$ activity (arambha) is a mark of only the living beings (both movable, as animals, and immovable, as vegetals); (b) activity is due to a particular spontaneous attitude (pravrttiviśeșa) that is peculiar to those living beings; $(c)$ this particular spontaneous attitude can be peculiar to living beings because in primis it is a mark of the material elements that constitute their parts, and manifests itself only when and where the elements attain the form and nature of a living being. Moreover, it is worth noting that $(d)$ cognition is by the materialist proved to belong to the material elements on the basis of its link with desire and aversion (as the sentence tadyogāj jūānayoga, "because there is conjunction with them, there is conjunction with cognition", reveals), which are seen in their turn as the marks of activity and inactivity.

All this reminds us of the abovementioned passage 12., in which Udbhațabhața speaks of a particular intrinsic nature (svabhāvaviśeșa, to compare with pravrttiviśeșa, "particular spontaneous attitude", of quotation 25.), which is described as a property (dharma, to compare with tadavayavavyūhalinga, "mark of the component limbs of those [bodies]", of quotation 25.) peculiar to the body, and which is able to experience pleasures, pains, desires and aversions.

The argument of the materialist against which Vātsyāyana directs his criticism seems, in any case, to have some weak aspect. Indeed, if the materialist upholds that desire and aversion exist where activity and inactivity exist, Vātsyāyana argues that activity and inactivity can be observed also in non living beings, as for instance in an axe (whose activity depends on someone's utilization of it). The fundamental critical point is, therefore, the following one: Vātsyāyana rejects the idea according to which

\footnotetext{
${ }^{27}$ The Sanskrit term anu generally refers to "atom". Atoms, according to certain philosophers (among which the Vaiśeșikas) would represent the basic particles of every material element (earth, water etc.). Although Vātsyāyana's reference to anus (atoms) is probably due to the fact that materialists known to him upheld atomism (see Sinha, 1952: p. 242), nonetheless we do not have any certain data on whether Cārvākas or other schools of materialism were atomists or not. A possible source in favour of Cārvākas' atomism could be for instance Gunaratnasūri's $\left(14^{\text {th }}-15^{\text {th }}\right.$ century CE) Tarkarahasyadīpikā (The lamp of subtle points on reasoning) on Haribhadrasūri's $\left(8^{\text {th }}\right.$ century CE) Șaḍdarśanasamuccaya (Collection of six points of view) verses $48-49$, where the materialistic point of view on this subject is explained as follows (Jain, 1981: p. 218): aṇavo'pi hy apratyakșāh kim tu ghațādikāryatayā parinatās te pratyaksatvam upayānti ("Although the atoms are imperceptible, nevertheless [when] developed into the condition of an effect [of their mixture,] like a jar etc., they gain perceptibility").
}

activity and inactivity are primarily defined as marks of bodies, which are in their turn thought to be an assemblage of different component parts, each of them subjected to activity and inactivity. Indeed, Vātsyāyana points out that also inanimate objects have parts - like for example a jar, which has a lip, handels etc.- , but nobody would admit that these parts do actually experience desire, aversion etc. It follows that $(A)$ cognition (and desire and aversion as well) cannot be a simple or mere property of the elements, otherwise it should be present in each element, with the consequence that every single body would have a number of cognitions according to as many elements concure to constitute it (Nyāyasūtrabhāsya ad Nyāyasūtra 3.2.37): ${ }^{28}$

26. bhütacaitanikasyaikaśarīre bahūni bhütāni jñānecchādveșaprayatnaguñānīti jñātrbahutvam prāptam |

"[If we accept the idea] of the adherent to the doctrine that cognition is from material elements, [then] the various material elements [present] in a single body [would each one] have the qualities of cognition, desire, aversion and effort; [thus, we will] come to a multitude of cognizers [in one and the same body]".

Cognition $(B)$ cannot be either a property of the parts that constitute a body as such, otherwise it would/should be present - according to Vātsyāyana's reasoning — in almost every body, because the majority of the existents are formed by different parts linked together (like in the case of a man, a jar etc.). This is, I think, a good example of the kind of criticism to which Udbhatabhatța intended to answer to with his reformulation of the Cārvāka idea of cognition: to admit that cognition is a bhütartha svatantra (a self-dependent thing consituted by material elements), as we have seen, allows Udbhațabhațta to confer to it a certain degree of autonomy from the body, on which it depends nonetheless in toto for its manifestation. Moreover, by virtue of its partial autonomy, cognition does not depend stricto sensu on bare elements (atoms etc.) or on the component limbs of a body tout court. Rather, it takes place as a - so to speak - added principle, but only when and where the elements are mixed up in a certain, precise manner, to constitute bodies whose parts are organized in a likewise certain and precise way. The concept of a svatantra (self-dependent) cognition, which is also a svabhāvaviśeșa (particular intrinsic nature) of the body, therefore, can represent a tentative dialectical response to both the abovementioned Vātsyāyana's objections $(A)$ and $(B)$.

\section{Conclusion}

Cognition, pleasure, pain etc., are defined by Udbhațabhațta both as principles and as properties of the human body, for distinguishing them from what we have called the bare properties, like colour, weight etc., which are characteristics not peculiar to human bodies, but belonging to every existing thing. Indeed, cognition, pleasure etc. are really of a particular nature, because they do not manifest themselves for all the time their substantial substratum remains present, as colour or weight actually do. This aspect - namely, the occasionality of cognition, pleasure etc. - marks a fundamental difference also with, for instance, the quality "inhebriating power" belonging to the substance "liquour" (see our aphorism 04.). When, in fact, the mixture of ferments, juices etc., develops its alcoholic degree, this alcoholic degree remains permanent in that very substance. In other terms, a case in which a liquour does not manifest the

\footnotetext{
${ }^{28}$ Sastri Tailanga (1984: p. 175). According to Sastri Tailanga's edition this is the commentary on Nyāyasütra 3.2.39.
} 
inhebriating power as its quality is not given, whereas we continuously have experience of ourselves enjoying pleasures and pains only on certain occasions. Also cognition takes place just when we cognize. Therefore, for instance, during the deep sleep the cognizing faculty is reputed to be suspended. This means that the simile of the liquour (the lion's roar of the materialistic conception of cognition), although being very attractive, does not represent with the due accuracy the relation existing between body and cognition. The learned Vātsyāyana should have remarked, and consequently criticized, exactly this kind of incongruences.

Udbhatabhatta tried, with his reformulation of the nature of cognition, to find a new definition of the psychological events that were, at one time, in line with the materialistic assumptions - according to which cognition would be nothing but a factor that is subordinated (note the compounds caitanyavisisțta, "characterized by cognition", in aphorism 05., and svabhāvaviseșa, "particular intrinsic nature", in quotation 12.) to the human body_, but more philosophically and dialectically articulated - although it is definded by him as svatantra (self-dependent), Udbhațabhațta's cognition is not at all an independent principle in the same way in which the four elements of the aphorism 01. are independent, and nonetheless it is less dependent on that four elements than a bare quality, such as colour, weight etc., is to conclude, we can suppose that Udbhațabhața did so for better preventing and/or rebutting some possible spiritualistic or anti-materialistic objections, among which those pointed out by Vātsyāyana undoubtedly represent a good example.

\section{Acknowledgments}

I would like to thank in particular Antonio Rigopoulos for having read a draft of this paper, for his comments and suggestions, Gianni Pellegrini for having discussed with me some among the Sanskrit passages quoted here and Chiara Zaccone for her valuable help in amending and refining the English text. Moreover, I would have never been able to draw up the present article without having been acquainted with the work and writings of Ramkrishna Bhattacharya - and without the intense epistolary relationship occurred between him and me, to whom I due all my knowledge of Cārvāka philosophy.

\section{References}

Bhattacharya, R. (2009). Studies on the Cārvāka/Lokāyata. Firenze: Società Editrice Fiorentina, Manohar.

Bhattacharya, R. (2010a). Commentators on the Cārvākasūtra: A critical survey. Journal of Indian Philosophy, 38, 419-430. doi:10.1007/s10781-010-9088-6

Bhattacharya, R. (2010b). What the Cārvākas originally meant. More on the commentators on the Cārvākasūtra. Journal of Indian Philosophy, 38, 529-542. doi:10.1007/s10781-010-9103-y

Bhāviveka, Prajñāpradīpamūlamadhyamakavrtti (Glosses on the Root stanzas on the middle called The lamp of wisdom). dBu ma' $i$ rtsa ba' $i$ 'grel pa śes rab gron ma, sDe-dge bsTan-'gyur, dBu-ma, TSHa, foll. $97,45 \mathrm{~b} 4-259 \mathrm{~b} 3$.

Bronkhorst, J. (1994). Once again Vaiśeșika Sūtra 3.1.13. Asiatische Studien/Études Asiatiques, 48, 665-681.
Candrānanda, Vaiśeșikasūtravṛtti (Glosses on The Vaiśeșika aphorisms). Jambuvijayaji (1961). Vaiśeșikasūtra of Kanāda with the commentary of Candrānanda. Baroda: Oriental Insitute.

Chakravarti, A. (1982). The Nyāya proofs for the existence of the soul Journal of Indian Philosophy, 10, 211-238. doi:10.1007/BF00240665

Comba, A. (2001). Carakasaṃhita, Śārī rasthāna I and Vaiśeșika philosophy. In G. Jan Meulenbeld and D. Wujastyk (Eds.), Studies on Indian Medical History, Delhi: Motilal Banarsidass, 39-55.

Dharmottara, Paralokasiddhi (The Proof of Re-birth). Steinkellner, E. (1986). Dharmottaras Paralokasiddhi: Nachweis der Wiedergeburt, zugleich eine Widerlegung materialistischer Thesen zur Natur der Geistigkeit (Dharmottara's Paralokasiddhi: The proof of re-birth, being at the same time a refutation of the materialistic theories of the nature of spirituality). Wien: Arbeitskreis für Tibetische und Buddhistische Studien Universität Wien (Vienna: Association for Tibetan and Buddhist Studies, University of Vienna).

Gautama, Nyāyasūtra (The Nyāya aphorisms). Chandra, S., Sinha, N. (1930). The Nyaya Sutras of Gotama. New Delhi: Ajay Book Service.

Guṇaratnasūri, Tarkarahasyadīpikā (The lamp of subtle points on reasoning). Jain, M. K. (1981). Saddarśanasamuccaya of Haribhadra Süri (with the commentaries Tarka-rahasya-dipikā of Gunaratnasūri and Laghuvrtti of Somatilaka Sūri and an Avacūrṇi) (2nd ed.). New Delhi: Bharatiya Jnanpith.

Halbfass, W. (1991). Tradition and reflection. Explorations in indian thought. Albany: SUNY Press.

He, H. (2011). Bhavya's critique of the Vaiśeșika theory of liberation in the Tarkajvālā. Studies in Indian Philosophy and Buddhism, 18, 23-37.

Kamalaśīla, Tattvasamgrahapañjikā (Running commentary on The collection of philosophical principles). Śāstrī, D. (1968). The Tattvasamgraha of Ācārya Śantarakșita with the "Pañjikā" commentary of Ācārya Kamalaśilla, Varanasi: Bauddha Bharati, 2.

Kaṇāda, Vaiśeșikasūtra (The Vaiśeșika aphorisms). Chakrabarty, D. (2003). Vaiśeșika Sütra of Kanāda. New Delhi: D.K. Printworld.

Kaṇāda, Vaiśeșikasūtra (The Vaiśseșika aphorisms). Gough, A. E. (1873). The Vaiśeshika Aphorisms of Kanâda with Comments from the Upaskâra of Śankara-Miśra and the Vivrtti of Jaya-NârâyanaTarkapañchânana. Benares: E. J. Lazarus \& Co., London: Trübner \& Co.

Kaṇāda, Vaiśeșikasūtra (The Vaiśeșika aphorisms). Sinha, N. (1923). The Vaiśeșika Sutras of Kanâda with the commentary of Śrikara Miśra and extracts from the gloss of Jayanârâyana and the Bhâsya of Chandrakânta. Allahabad: Vijaya Press.

Matilal, B. K. (1977). Nyāya-Vaiśeșika. Wiesbaden: Otto Harrassowitz.

Solomon, E. A. (1972). Aviddhakarna-A forgotten Naiyāyika. Proceedings of the All-India Oriental Conference (Twenty-fifth Session, Jadavpur University, Calcutta, October 1969), 25, 337-352.

Solomon, E. A. (1977-1978). Bhațta Udbhața. Annals of the Bhandarkar Oriental Research Institute, 58-59, 986-987.

Thakur, A. (2003). Origin and development of the Vaiśeșika system. New Delhi: Project of History of Indian Science, Philosophy, and Culture, Center for Studies in Civilizations.

Vādidevasūri, Syādvādaratnākara (The jewel mine of the doctrine of "may be"). Osval, M. L. (1988). Syādvādaratnākara of Vādideva Sūri. Delhi: Bharatiya Book Corporation.

Vātsyāyana, Nyāyasūtrabhāsya (Commentary on The Nyāya aphorisms). Nyaya-Tarkatirtha, T., Tarkatirtha, A. (1936-1944). Nyāyadarśanam: with Vātsyāyana's Bhāṣya, Uddyotakara's Vārttika, Vācaspati Miśra's Tātparyațīkā and Viśvanātha's Vrrtti. Calcutta: Metropolitan Printing \& Publ.

Vātsyāyana, Nyāyasūtrabhāṣya (Commentary on The Nyāya aphorisms). Sastri Tailanga, G. (1984). The Nyāyasutras with Vātsyāyana's Bhāsya and extracts from the Nyāyavārttika and the Tatparyatika (2nd ed.). Delhi: Sri Satguru Publications. 